\title{
Efficacy and safety of the use of omalizumab in a patient with difficult-to-control severe asthma and antiphospholipid antibody syndrome
}

\author{
Rosangela Villela ${ }^{1 *}$, Janaina M Melo ${ }^{1}$, Thais Nociti ${ }^{1}$, Ana Carla S Araujo ${ }^{1}$, L Karla Arruda ${ }^{2}$ \\ From 3rd WAO International Scientific Conference (WISC) 2014 \\ Rio de Janeiro, Brazil. 6-9 December 2014
}

\section{Background}

Autoimmune conditions may be associated with allergic diseases. There are few studies on the safety of omalizumab use in patients with asthma who also present autoimmune disease.

\section{Methods}

Case report of a patient with severe asthma associated with antiphospholipid antibody syndrome (APS) treated with omalizumab.

\section{Results}

Female, 36-year-old patient, with uncontrolled asthma, dependent on oral corticosteroid. Patient had a history of cough, wheezing and dyspnea since childhood with worsening in the past few years, with dyspnea on minimal activities and use of rescue albuterol 3-10 times a day. She had a history of intensive care unit admission and intubation for asthma on two occasions. Associated conditions were: APS (thrombosis of the leg, miscarriage, stillbirth and positive lupus anti-coagulant, use of aspirin, depression, GERD, and allergic rhinitis. She was on Formoterol/Budesonide $12 / 400 \mathrm{mcg}$ plus inhaled Beclomethasone $800 \mathrm{mcg}$ twice daily; Montelukast $10 \mathrm{mg}$ a day; Prednisone $5 \mathrm{mg}$ daily; Fluoxetine $40 \mathrm{mg}$ daily; nasal Budesonide 50mcg twice a day; Omeprazole 20mg once a day.

Her initial spirometry showed an FEV1 of $47 \%$ predicted, with response to bronchodilator $(21 \%$ and $300 \mathrm{~mL}$ reversibility). This pattern remained throughout her follow up in our Clinic. Her total IgE was $120 \mathrm{kU} / \mathrm{L}$, and she presented positive skin prick tests to Dermatophagoides

${ }^{1}$ School of Medicine of Ribeirao Preto - University of Sao Paulo, Brazil Full list of author information is available at the end of the article pteronyssinus, $D$. farinae and Trichophyton and negative to Aspergillus. Chest tomography and bronchoscopy were unremarkable.

Despite correct use of medications, the patient had frequent exacerbations and need for increasing doses of oral prednisone up to $80 \mathrm{mg}$ daily, with weight gain of $18 \mathrm{~kg}$ in 3 years. Omalizumab was started, and within two weeks the patient showed marked improvement of symptoms, making it possible to withdraw prednisone. There was reduction in use of rescue albuterol, improvement in quality of life and weight loss. After 9 months, treatment with omalizumab was discontinued due to supply problems, with worsening of asthma and return of oral corticosteroids. Provision of omalizumab was restored after 6 months, and the patient again had improvement of symptoms and discontinuation of oral corticosteroids. Currently, she uses rescue bronchodilator 2 times a week, lost $20 \mathrm{~kg}$ and practices physical activity.

\section{Conclusions}

Omalizumab was very effective in controlling symptoms in a patient with severe asthma and APS. No adverse effects related to medication use were observed.

\section{Consent}

Written informed consent was obtained from the patient for publication of this abstract and any accompanying images. A copy of the written consent is available for review by the Editor of this journal.

\section{Authors' details}

${ }^{1}$ School of Medicine of Ribeirao Preto - University of Sao Paulo, Brazil.

${ }^{2}$ Brazilian Association of Allergy and Immunology, Brazil. 
doi:10.1186/1939-4551-8-S1-A219

Cite this article as: Villela et al.: Efficacy and safety of the use of omalizumab in a patient with difficult-to-control severe asthma and antiphospholipid antibody syndrome. World Allergy Organization Journal 2015 8(Suppl 1):A219.

Submit your next manuscript to BioMed Central and take full advantage of:

- Convenient online submission

- Thorough peer review

- No space constraints or color figure charges

- Immediate publication on acceptance

- Inclusion in PubMed, CAS, Scopus and Google Scholar

- Research which is freely available for redistribution

Submit your manuscript at www.biomedcentral.com/submit 